\title{
Primary Occupation Code
}

National Cancer Institute

\section{Source}

National Cancer Institute. Primary Occupation Code. NCI Thesaurus. Code C93632.

A coded value specifying the principal activity that a person does to earn money. 